\title{
Effects on inactivation of Tetraselmis suecica following treatment by KBAL: a UV-based ballast water treatment system with an in-line vacuum drop
}

\author{
Ranveig Ottoey Olsen ${ }^{1} \cdot$ Gunnar Thuestad $^{1} \cdot$ Ingunn Alne Hoell ${ }^{1}$
}

Received: 19 February 2020 / Accepted: 13 May 2020 / Published online: 27 May 2020

(c) The Author(s) 2020

\begin{abstract}
The transfer of non-native, possibly invasive species in ship's ballast water is of global concern, and the International Maritime Organization and U.S. Coast Guard have adopted standards to minimize the environmental footprint caused by the maritime industry. In this study, seawater spiked with the phytoplankter Tetraselmis suecica, was treated with Knutsen Ballast Water Treatment Technology (KBAL), combining UV irradiation with an in-line vacuum drop. The test water was subsequently incubated in dark tanks, simulating what happens onboard a ship, where ballast water is treated at intake, stored in dark ballast tanks during the voyage, and then treated at discharge. Our results of the test water treated with KBAL and stored 5 days in the dark showed $<10$ viable $T$. suecica cells $\mathrm{ml}^{-1}$ when assessing reproduction and $>10$ living cells $\mathrm{ml}^{-1}$ when assessing metabolism. This highlights the challenge UV-based BWTS can encounter when meeting testing regimes assessing different characteristics of life. By comparing the effects caused by KBAL treatment with effects caused by UV irradiation only, we demonstrated that the pressure/vacuum technology seems to improve the disinfection effect. In addition, our investigations point out possible challenges with in situ conditions getting representative ballast water samples.
\end{abstract}

Keywords Ballast water $\cdot \mathrm{KBAL} \cdot$ Pressure/vacuum $\cdot \mathrm{UV} \cdot$ Tetraselmis suecica

\section{Introduction}

Non-native, possibly invasive species in ship's ballast water can cause ecological changes and threat the biological diversity and the economy. The transfer of organisms is of global concern, and the International Maritime Organization (IMO) and U.S. Coast Guard (USCG) have adopted standards to minimize the environmental footprint caused by the maritime industry $[1,2]$. In response to this, vendors have developed different ballast water treatment systems (BWTS). The commercialization rely on BWTS type approvals, which includes land-based tests and shipboard trials [3, 4]. One of these systems, the Knutsen Ballast Water Treatment Technology (KBAL) developed by Knutsen OAS Shipping AS, combines UV irradiation with an in-line vacuum drop. The developers aimed at avoiding chemicals to fulfill

Ranveig Ottoey Olsen

ranveig.olsen@hvl.no

1 Western Norway University of Applied Sciences, Bjoernsonsgt. 45, 5528 Haugesund, Norway the G8-guidelines of the type approval process. It was also important for them to remove any filtration steps for water purification, due to maintenance concerns onboard ships. KBAL was type approved by IMO in 2016, and the commercialized KBAL system can treat ballast water at intake, during the voyage and/or at discharge. By December 2019, KBAL is the only BWTS on the marked that uses pressure/ vacuum $(\mathrm{P} / \mathrm{V})$ and UV irradiation as a treatment technology [5]. Most other BWTS combine UV irradiation with filtration [5]. Only two additional UV-based BWTS sidestep filtration; OceanDoctor BWTS produced by Jiujiang Precision Measuring Technology, instead uses an active substance $(\mathrm{OH} \bullet)$ and is type approved according to the $\mathrm{G} 9$ guidelines; and BSKYTM BWMS produced by Wuxi Brightsky, which combines UV irradiation with a centrifugal separator [5].

Although not very common in BWTS, the use of P/V technology is well-known from other industry processes, for example as a physical pretreatment for extraction of microbial products [6]. The process is called high-pressure homogenization, where a liquid is transported with high pressure through a very narrow nozzle, causing a sudden drop in pressure causing cavitation, which induces destruction of the 
(a)

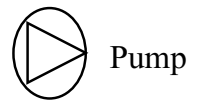

$\longrightarrow$ Pipe

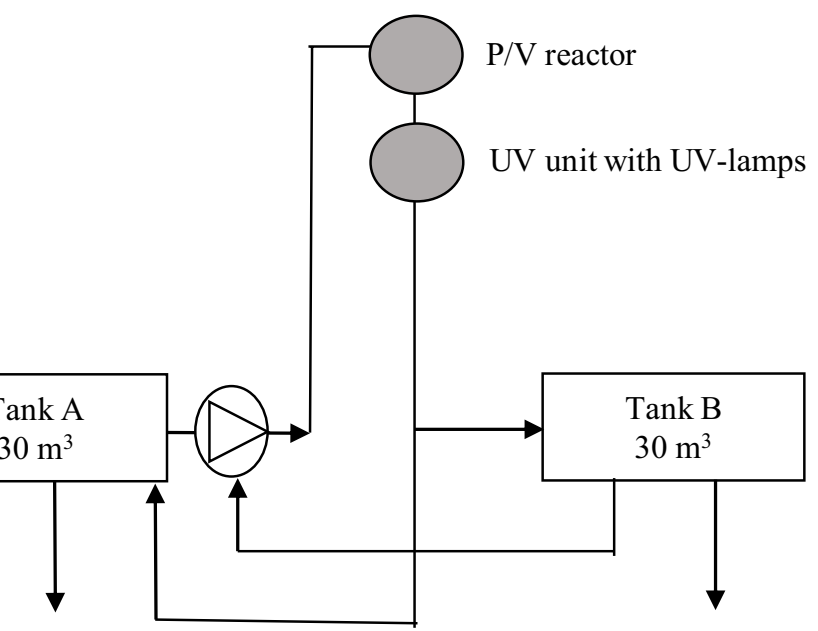

Discharge

Intake

Discharge

Discharge

(b)

Inlet pressure
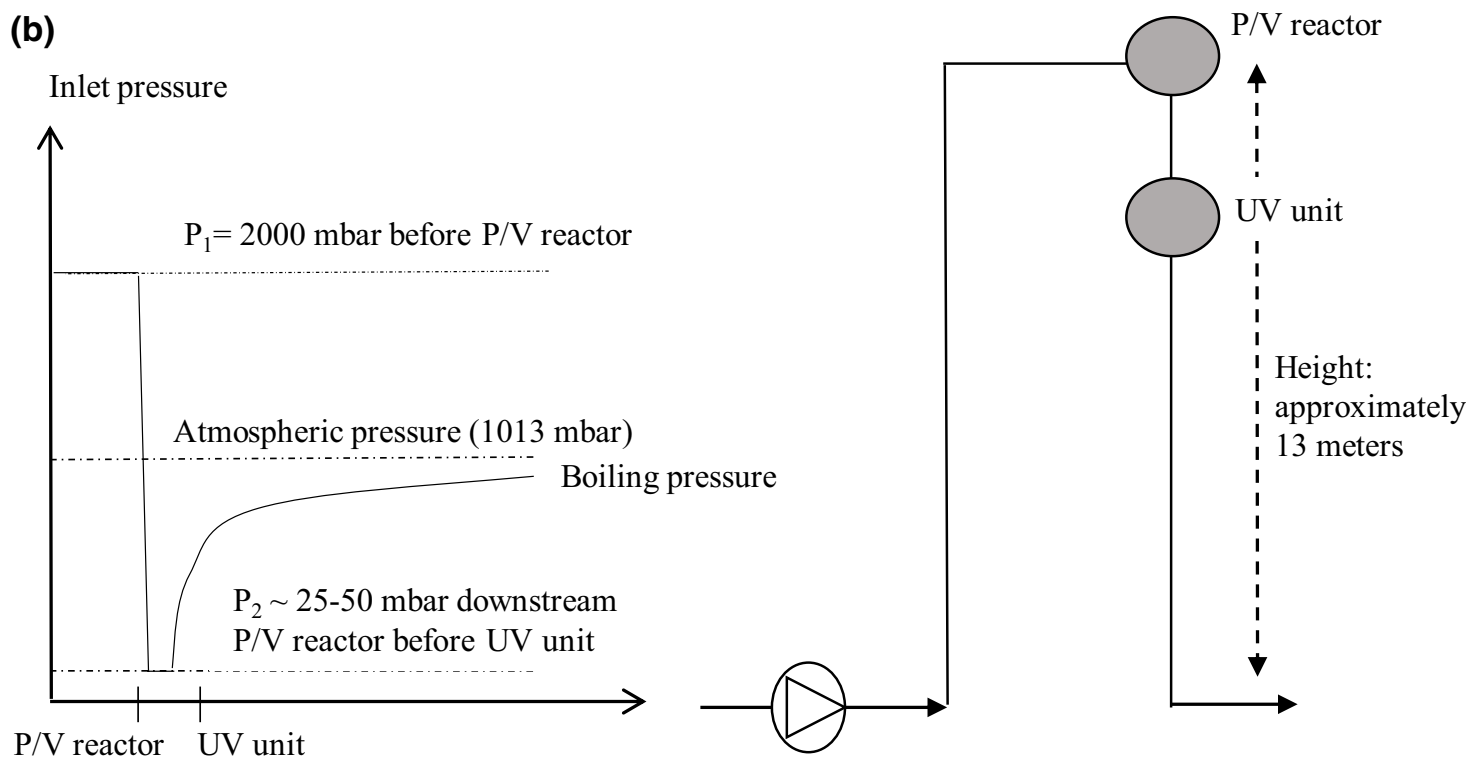

Distance downstream $\mathrm{P} / \mathrm{V}$ reactor

(c)

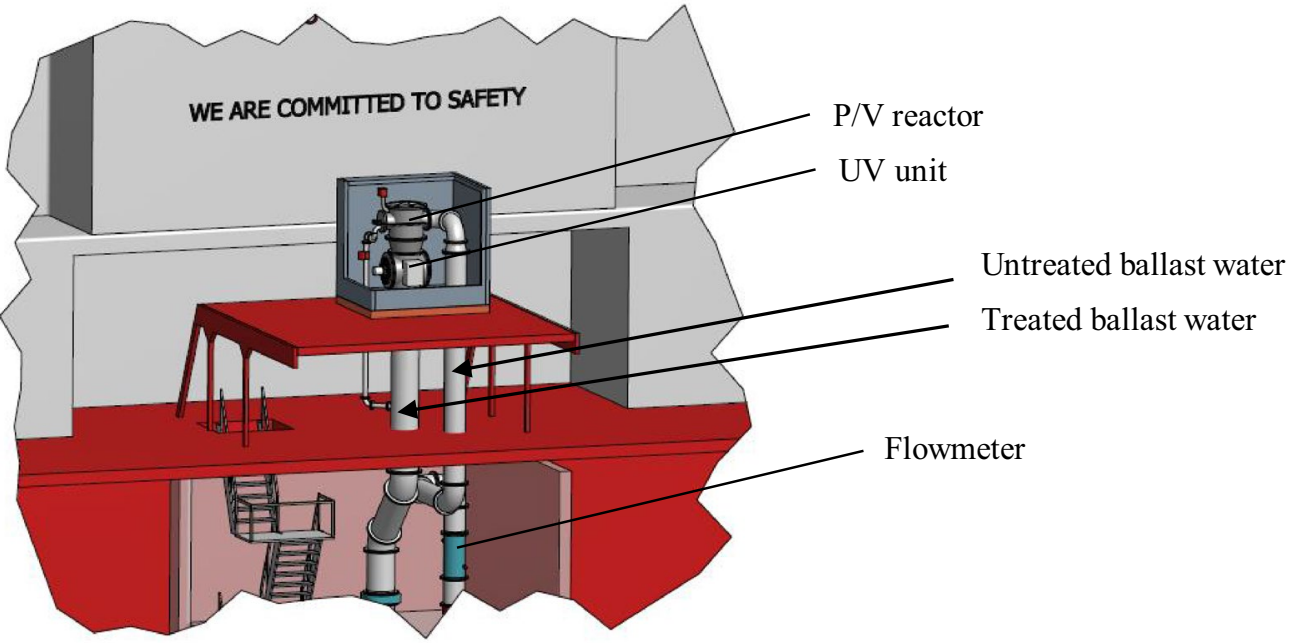


४Fig. 1 Schematic drawings explaining a how the pumps, pipes and tanks are arranged in the KBAL test rig, where we have performed the experimental part, $\mathbf{b}$ the basic principle of the technology, and $\mathbf{c}$ how the technology is implemented onboard a ship. The ballast water is pumped into the $\mathrm{P} / \mathrm{V}$ reactor that works in combination with a vertically drop line followed by a UV unit for irradiation. The water drop line below the $\mathrm{P} / \mathrm{V}$ reactor will cause a subsequent reduction in pressure, so that the water reaches its boiling point. Figures are used with permission from the inventor of the technology in Knutsen OAS Shipping

cells leading to inactivation [7]. The high-pressure homogenization technology is easy to operate, cost and time effective, and can be used for large volumes. It also has the ability to reduce particle sizes [8], and it has been demonstrated that multiple rounds of high-pressure homogenization gives an additive effect on viability reduction [7].

UV irradiation is a more commonly used ballast water treatment technology, installed in various ship types [5, 9]. UV irradiation affects the genetic material in organisms, possibly inhibiting replication and transcription $[10,11]$. The low-pressure (LP) and medium-pressure (MP) mercury UV lamps are emitting monochromatic UV irradiation at $254 \mathrm{~nm}$, or a broader spectrum of wavelengths between 200 and $400 \mathrm{~nm}$, respectively. Studies have shown that MP UV lamps have a higher disinfection capacity compared to LP UV lamps [12-14] and MP UV lamps have higher power output than LP UV lamps. Therefore, the numbers of MP UV lamps needed in a UV-based BWTS is reduced compared to a system based on LP UV lamps. In addition, MP UV lamps are shorter and more compact, reducing the size of the UV reactor. When retrofitting ships with BWTS, ship owners and operators concern about power consumption and footprint parameters, and using MP UV lamps can be beneficial with respect to minimal footprint and low power consumption compared to LP UV lamps. UV treatment has many benefits; it is considered environmentally friendly, no neutralization of chemicals is needed, it has low risk to operators and requires little training and maintenance, and parameters such as $\mathrm{pH}$ and temperature does not influence the UV-lamp functionality $[15,16]$. Furthermore, microorganisms can employ survival strategies, such as cyst formation, when exposed to periods of unfavorable conditions [9]. Cysts have been recognized in ships' ballast tanks [10], and cysts can be resistant to various disinfectants [11, 12]. However, UV irradiation has been shown to inhibit cyst germination of Giardia species and algae [13, 14, 17]. On the other hand, biotic and abiotic particles in seawater can affect the BWTS inactivation, by protecting and shielding microorganisms during UV treatment [18, 19]. In addition, fouling of the quartz sleeves housing the UV lamps may reduce its efficiency by absorbing radiation that would otherwise be available for disinfection [20-22].
In this study, Tetraselmis suecica was used as a challenge organism for validation of the KBAL system. T. suecica is a representative of the $\geq 10$ to $<50 \mu \mathrm{m}$ size class of the D-2 discharge standard, and belongs to the prasinophytes [23]. Several studies have previously argued that Tetraselmis is well suited as a standard test organism for validation of UVbased systems, since they are more or at least as resistant to LP and MP UV treatments as other naturally occurring seawater organisms, and do not generate a positive or negative bias to any technology $[24,25]$. We used a dual staining flow cytometry (FCM) protocol with 5-carboxyfluorescein diacetate acetoxymethyl ester (CFDA-AM) and SYTOX Blue [26], plate count analysis, and a most probable number (MPN) analysis to analyze the effect of the treatments. We aimed at answering the following questions:

(1) Are the vitality and viability results from the KBAL test in accordance with the IMO and USCG regulations?

(2) How does the KBAL technology affect the cells?

\section{Materials and methods}

\subsection{Culture maintenance}

The phytoplankter Tetraselmis suecica (K-0297) was obtained from the Scandinavian Culture Collection of Algae and Protozoa (University of Copenhagen, Denmark), and cultured in $36 \mathrm{~g} / \mathrm{kg}$ artificial seawater (ASW) (Marine SeaSalt, Germany) supplemented with $0.12 \%$ Substral (The Scotts Company (Nordic) A/S, Denmark). The cultures were incubated at room temperature $\left(23-24^{\circ} \mathrm{C}\right)$ under fluorescent light (T5 (25 W), and T8 (18 W) Sylvanian Grolux fluorescent tubes) in two $100 \mathrm{dm}^{3}$ glass aquariums with aeration, filled with $\sim 70 \mathrm{dm}^{3}$ algal culture each. The amount of motile cells were detected in a counting chamber in an Optiphot-2 microscope (Nikon, Japan) by subtracting the number of non-motile cells from the number of total cells in an equivalent heat-killed sample. In addition, the quantification and viability were tested by growth on $1 \%$ Bacto $^{\text {TM }}$ Agar (Difco Laboratories, Becton, Dickinson and Company, France) in artificial seawater with salinity of $24 \mathrm{ppt}$ (which is normal along the Norwegian coast and fjords) supplemented with $0.12 \%$ Substral. A minimum of 1000 motile cells $\mathrm{ml}^{-1}$ were added during tests in the KBAL test rig.

\subsection{Treatment at the KBAL test rig}

A $50 \mathrm{~m}^{3} / \mathrm{h} \mathrm{KBAL}$ test rig is located in Haugesund, Norway. In the KBAL treatment system (Fig. 1a), water is pumped into a P/V reactor (Knutsen OAS Shipping AS, Norway). The water drop line below the $\mathrm{P} / \mathrm{V}$ reactor (approximately $13 \mathrm{~m}$ ) will cause a subsequent reduction in pressure, so 
that the water reaches its boiling point (Fig. 1b). This almost immediate pressure to vacuum process will have a negative effect on microorganism. In addition, the vacuum process will enhance inactivation by the UV irradiation, by ensuring a more evenly distribution of particles in the water stream and thus reducing the shadowing effects. The UV unit has 4 MP UV lamps $(1.1 \mathrm{~kW}$, polychromatic mercury lamp) (BestUV, The Netherlands) (Fig. 1a). A typical ship installation is illustrated in Fig. 1c. The test rig consists of two $30 \mathrm{~m}^{3}$ tanks, one for test water (A), and one for storage of the water after treatment (B) (Fig. 1a). In addition, there was a $1 \mathrm{~m}^{3}$ tank for seawater (C) (Fig. 1a). Before this test, the tanks were washed with a high-pressure hose and the system was flushed with municipal drinking water.

Tank A was filled with approximately $20 \mathrm{~m}^{3}$ seawater obtained from 1 to $2 \mathrm{~m}$ depth in Smedasundet, Haugesund, Norway, on the 2. November 2016. The temperature of the seawater was $11^{\circ} \mathrm{C}$ at the time. At the same time, $400 \mathrm{~g}$ Kaolin (Sigma-Aldrich, product number 18672, CAS number 1332-58-7) and $430 \mathrm{~g}$ Maizena (Unilever Norge AS, Knorr, product number 2041499) were added, as well as T. suecica culture to a final concentration of minimum 1000 motile cells $\mathrm{ml}^{-1}$ (test water). To ensure mixing, three extended outboard electric motors (Biltema, product number 25-235) (propeller: two blades, $240 \mathrm{~mm}$ in diameter) were used at maximum speed (corresponding to a $15.4 \mathrm{~kg}$ thrust) for about $30 \mathrm{~min}$. During the first treatment, the test water was pumped with a flow of $50 \mathrm{~m}^{3} \mathrm{~h}^{-1}$. The theoretical UV dose was set to $100 \mathrm{~mJ} \mathrm{~cm}^{-2}$ for UV transmittance (UVT) at $60 \%$, though the UVT measured by a UVT10-meter (BestUV, The Netherlands) was $86 \%$. During treatment, the pressure was set to 2000 mbar upstream the P/V reactor and measured to 25-50 mbar downstream the reactor before the UV chamber. The treated test water was stored in tank B for 5 days, and subsequently mixed with the outboard electric motors for about $30 \mathrm{~min}$ at maximum speed, followed by a second treatment on the 7. November 2016 with the same conditions as during the first treatment. Untreated test water was stored in tank $\mathrm{C}$ for 5 days, and prior to sampling at day 5 , the water in this tank was mixed with a paddle.

Samples were collected as follows:
(1) Seawater.

(2) Test water (seawater added T. suecica, Kaolin and Maizena).

(3) Test water treated once.

(4) Untreated test water and subsequently 5 day holding time.

(5) Test water treated once and subsequently 5 day holding time.

(6) Test water treated twice, including 5 day holding time between the treatments.

Table 1 summarizes how the seawater and test water was stored and/or treated.

Three parallel bottles of approximately 11 were collected for each sample, except for sample number 5 , where only one bottle was collected. The bottles were stored in the lab at $15^{\circ} \mathrm{C}$ in the dark after sampling. Notice that the 5 day holding time for sample 4, 5 and 6 were in dark outdoor tanks of the KBAL test rig, further incubation was at $15^{\circ} \mathrm{C}$ in the lab. The air temperature these 5 days of outdoor storage varied between $-0.7{ }^{\circ} \mathrm{C}$ and $5.1{ }^{\circ} \mathrm{C}$.

\subsection{Ballast water analysis}

Prior to analysis with the attune acoustic focusing cytometer (Thermo Fisher Scientific), $30 \mathrm{ml}$ of the samples were filtered through a $100 \mu \mathrm{m}$ nylon filter (BD Falcon Cell strainer $100 \mu \mathrm{m}$ nylon, ref. 352360, BD, USA) to prevent large organisms and/or particles from clogging the tubing of the FCM instrument. All samples were dual stained with the esterase substrate CFDA-AM (C1354, Thermo Fisher Scientific, USA) and SYTOX Blue Dead Cell Stain (S34857, Thermo Fisher Scientific, USA), as described previously [26]. $4 \mathrm{ml}$ of each sample was analyzed at a flow rate of $1000 \mu \mathrm{min}^{-1}$ and the sample dispensed options were set at standard collection mode. The trigger was set at red fluorescence (BL3 detector) and the threshold at 10,000. Samples 1, 2 and 3 were analyzed at day 0 ( $2 \mathrm{~h}$ after sampling), 1, 2, 5, $6,7,8,9$, and 12 , whereas samples 4,5 , and 6 were analyzed at days 5, 6, 7, 8, 9 and 12 .

To determine the numbers of viable cells, plate count analysis was performed and the cells were cultured on $1 \%$
Table 1 Summarizes how the seawater and test water was stored and/or treated

\begin{tabular}{lllll}
\hline $\begin{array}{l}\text { Sample } \\
\text { number }\end{array}$ & Content & $\begin{array}{l}\text { KBAL treat- } \\
\text { ments }\end{array}$ & Holding time in KBAL tanks & $\begin{array}{l}\text { Number of } \\
\text { replicates }\end{array}$ \\
\hline 1 & Sea water & 0 & 0 days & 3 \\
2 & Test water & 0 & 0 days & 3 \\
3 & Test water & 1 & 0 days & 3 \\
4 & Test water & 0 & 5 days in tank C $\left(1 \mathrm{~m}^{3}\right)$ & 3 \\
5 & Test water & 1 & 5 days in tank B $\left(30 \mathrm{~m}^{3}\right)$ & 1 \\
6 & Test water & 2 & 5 days in tank B (between treatments) & 3 \\
\hline
\end{tabular}


Bacto $^{\mathrm{TM}}$ Agar (Difco Laboratories, Becton, Dickinson and Company, France) in artificial seawater with salinity of 24 ppt supplemented with $0.12 \%$ Substral. The agar plates were incubated in light at $36 \mathrm{~W} \mathrm{~m}^{-2}$ at $15^{\circ} \mathrm{C}$ for 14 days. The number of colony forming units (cfu) for each plate was determined, and the mean values of the three replicates were calculated (except for sample 5, where only one sample was analyzed). In addition, MPN analysis was performed as described previously [27]; however, continuous light was used during incubation. Positive (visible by eye) growth were scored against an MPN table for a three-replicate design [28].

\section{Results}

\subsection{FCM results of dual stained Tetraselmis suecica}

The $T$. suecica cells passed the laser light sources in the FCM instrument, one cell at a time. FCM signals are here presented as dot plots (Figs. 2, 3 and 5), where each dot represents one cell. Figure 2 shows forward scatter (FSC) intensity on the $x$-axis. FSC intensity is proportional to the diameter of the cell due to light diffraction around the cell. The $y$-axis shows the intensity of red autofluorescence. Since phytoplankton contain chlorophyll, the cells emit red autofluorescence when excited with a blue $(488 \mathrm{~nm})$ laser. A gate (black frame) defines the T. suecica population used for further vitality analysis. Since red autofluorescence from $T$. suecica cells was slightly reduced during the incubation period, the gate was designed to include these cells (Fig. 2a). At the same time, the gate was contracted to exclude other marine organisms and/or particles in the seawater (Fig. 2b).

The cells inside the gate (Fig. 2a) was subsequently presented in a dot plot with blue fluorescence on the $x$-axis and green fluorescence on the $y$-axis (Fig. 3), displaying membrane permeability and esterase activity, respectively. These dot plots were separated into 4 quadrants (Q) by a vertical and a horizontal line based on the green and blue fluorescence intensity from the cells, as described previously [26]. The quadrants reflect the physiological cellular characteristics of esterase activity and membrane permeability, and thus vitality. The cells in Q1 are live (high esterase activity and low membrane permeability/intact membrane), severely damaged in Q2 (high esterase activity and high membrane permeability), and dead in Q3 and Q4 (low esterase activity with either low (Q3) or high (Q4) membrane permeability). The low blue fluorescence in Q3 can be explained by degradation of DNA/RNA resulting in fewer or no binding sites for the SYTOX Blue stain [29].

As expected, the FCM analysis detected organisms with esterase activity (Q1), $44 \pm 15$ org. $\mathrm{ml}^{-1}$, in sample 1 (seawater) (Fig. 3a). These signals were most likely not caused by $T$. suecica cells, since cultivation methods did not show growth of this phytoplankter (Tables 2 and 3). The numbers of signals decreased during incubation.

For sample 2 (untreated test water, incubated in the lab), most cells were live (Q1) during the entire incubation period (Fig. 3). An FCM population (= single cells grouped together based on their fluorescence signals) appeared in Q2 (severely damaged cells) at days 0,1 and 2; however, this FCM population disappeared at day 5 and was absent during the rest of the analysis period. FCM results for sample 2 and sample 4 (untreated test water, stored in $1 \mathrm{~m}^{3}$ outdoor KBAL tank for 5 days) (Fig. 3) match perfectly from day 5, where most cells were detected as live (Q1) during the entire storage period. The numbers of live cells in sample 2 and 4 varied for the three replicates at some of the analysis days, as seen in the standard deviations (SD) for the three replicates analyzed (Fig. 4).
Fig. 2 FCM dot plots of the gate (black frame) used to define the Tetraselmis suecica population used for vitality analysis (Fig. 3). a Analysis of the lab-culture before added to the KBAL test rig, 10,000 cells were analyzed. b Analysis of $1 \mathrm{ml}$ seawater sample (dual stained) shows that most other organisms and/or particles were excluded from the gate
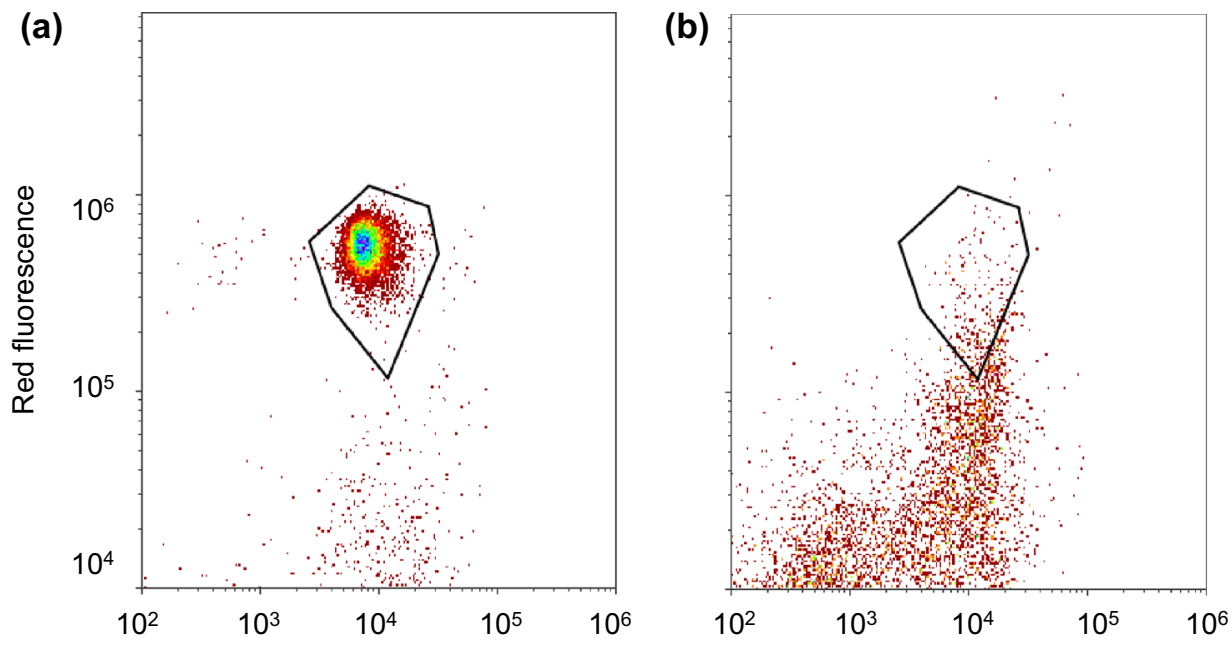

Forward scatter 


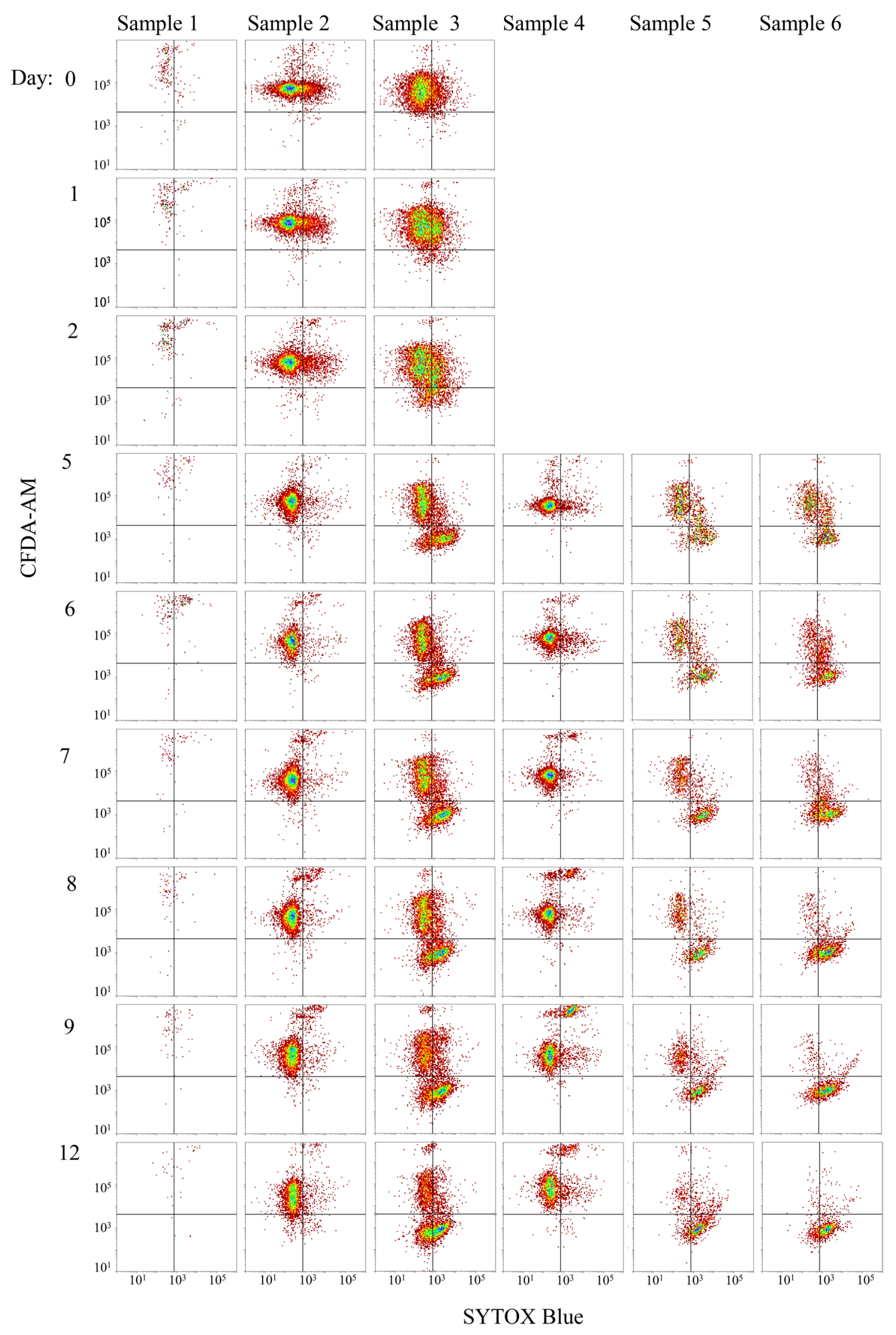


4Fig. 3 FCM dot plots of Tetraselmis suecica stained with SYTOX Blue ( $x$-axis) and CFDA-AM ( $y$-axis). The vertical columns show results for sample 1-6. For an overview of the various samples, see Table 1. The horizontal rows show the number of days of incubation. Notice that samples 4-6 were analyzed only from day 5, due to the holding time in outdoor KBAL tanks prior to sampling. Intersections in the dot plots separate signals into 4 quadrants (Q1-Q4)

The FCM signals for sample 3 (test water treated once, incubated in the lab) followed a pattern as previously described [26]. The cells were in Q1 (live) at day 0 with some cells in Q2 (severely damaged), and the population in Q2 increased during days 1 and 2 (Fig. 3). When comparing sample 3 with sample 5 (test water treated once, stored in $30 \mathrm{~m}^{3}$ outdoor KBAL tank for 5 days) (Fig. 3), the results from days 5-12 show the same reduction of cells in Q1 (live), an increasing population of damaged cell in Q2, and also an increase of dead cells in Q3/Q4 over time. Our results show that there were fewer cells in the sample with 5 day holding time in the outdoor KBAL tank (sample 5), only $\sim 50$ cells $\mathrm{ml}^{-1}$ live cells at day 12 , compared to $\sim 400$ cells $\mathrm{ml}^{-1}$ for sample 3 . When comparing the FCM results of sample 2 (untreated test water) with sample 3 (test water treated once) (Fig. 3), both incubated under similar conditions in the lab, less esterase activity and more variance in the fluorescence intensity was observed in sample 2 immediately after treatment.

The FCM signals for sample 6 (test water treated twice) also follow the Q1-Q2-Q3/Q4 pathway, similar to the samples treated once (samples 3 and 5) (Fig. 3). When comparing the second treatment with the first treatment (Fig. 3), both with a 5 day holding time in the outdoor KBAL tank, the cells died more rapidly when treated twice, meaning that cells were detected earlier in Q3/Q4. In addition, the numbers of cells in Q1 decreased more rapidly due to the second treatment (Fig. 4).

To get an indication on effects caused by the P/V technology, the results of $T$. suecica cells treated at the KBAL test rig were compared with previous results from $T$. suecica cells treated with UV irradiation only. Dot plot analyses from days $0,1,2$ and 7 of seawater (sample 1) and test water treated once at the KBAL test rig (sample 3) were compared to a sample irradiated with an MP UV lamp at $100 \mathrm{~mJ} \mathrm{~cm}^{-1}$ [26] (Fig. 5). The cells exposed to UV only, first lost their membrane permeability followed by a loss of esterase activity. On the other hand, cells treated with KBAL lost both membrane permeability and esterase activity simultaneously.

\subsection{Plate count and MPN}

Parallel to the FCM analysis, the samples were analyzed by the cultivation methods plate count (Table 2) and MPN (Table 3) to examine the numbers of viable cells (i.e., reproductive).
No viable $T$. suecica cells were detected by plate count (Table 2) in the seawater (sample 1) during the analysis period. The plate count results showed a reduction of viable cells over time in samples 2-6. The numbers of viable cells for both the untreated test water samples (sample 2 and sample 4), was reduced during the analysis period to $\sim 50 \%$ (>500 org. $\mathrm{ml}^{-1}$ ) at day 12. Sample 3 (test water treated once, incubated in the lab) showed $6 \pm 5$ viable cells $\mathrm{ml}^{-1}$ after 2 days, and $<3$ viable cells $\mathrm{ml}^{-1} 5-12$ days after treatment. Sample 5 (test water treated once, stored in KBAL tank for 5 days) (one sample only), showed $<10$ viable cells $\mathrm{ml}^{-1}$ when analyzed at days 5-12. Sample 6 (test water treated twice) showed $<3$ viable cells $\mathrm{ml}^{-1}$ immediately after the second treatment and throughout the incubation period.

The MPN results (Table 3) also showed a reduction of viable cells over time in all samples analyzed. An exception was results for sample 2 (untreated test water) at day 7 , as well as sample 4 (untreated test water with 5 day holding time in $1 \mathrm{~m}^{3}$ outdoor KBAL tank) at day 12, which both had higher numbers of viable cells compared to previous days. Since only one bottle was collected from the first treatment stored 5 days in the $1 \mathrm{~m}^{3}$ outdoor KBAL tank (sample 5), no MPN results were available for this sample.

\section{Discussion}

Both IMO and USCG have similar test water requirements when it comes to minimum concentration of organisms needed during land-based testing. For the $\geq 10$ to $<50 \mu \mathrm{m}$ size class, $\geq 1000 \mathrm{org}$. $\mathrm{ml}^{-1}$ is required at intake, $>100 \mathrm{org}$. $\mathrm{ml}^{-1}$ is required in the control discharge, and $<10$ org. $\mathrm{ml}^{-1}$ in the treated discharge according to the D-2 discharge standard [1, 3, 4]. We added a minimum of 1000 motile cells $\mathrm{ml}^{-1}$ to the test water, and during our 12 day analysis period, > 500 T. suecica cells $\mathrm{ml}^{-1}$ remained viable and living in the control samples, verifying that the test conditions were according to the requirements. Our land-based test mimics what happens onboard a ship: the ballast water is treated at intake (1st treatment), then stored in dark ballast tanks during the voyage (the 5 day holding time), and then treated again at discharge (2nd treatment).

A lesson learned from sampling is that the number of live T. suecica cells can easily be biased under variable conditions. For example, we experienced that cell concentration most likely was underestimated after the 5 day holding time, due to difficulties with mixing in the storage tanks. A previous study with known cell density of $T$. suecica culture in a storage tank, showed that the cell concentration was underestimated at discharge [30]. Tetraselmis species have three life stages, including flagellated, vegetative non-motile, and cyst stages [23]. Tetraselmis species in the cyst stage lose their flagella [23], and vegetative non-motile cells and 
Table 2 Plate count results for samples $1-6$ at different analysis days. The first day of analysis for samples 4-6 were at day 5 , since these samples were stored in outdoor KBAL tanks for 5 days prior to sampling. Data are means $( \pm 1 \mathrm{SD})$ of 3 replicates, except for sample number 5 , where only 1 bottle was collected

\begin{tabular}{|c|c|c|c|c|c|c|}
\hline \multirow[t]{2}{*}{ Analysis day } & \multicolumn{6}{|c|}{ Sample } \\
\hline & 1 & 2 & 3 & 4 & 5 & 6 \\
\hline 0 & $<3$ & $1058 \pm 124$ & $488 \pm 64$ & & & \\
\hline 1 & $<3$ & $988 \pm 117$ & $133 \pm 5$ & & & \\
\hline 2 & $<3$ & $809 \pm 158$ & $6 \pm 5$ & & & \\
\hline 5 & $<3$ & $621 \pm 76$ & $<3$ & $836 \pm 55$ & $<10$ & $<3$ \\
\hline 6 & $<3$ & $688 \pm 252$ & $<3$ & $839 \pm 127$ & $<10$ & $<3$ \\
\hline 7 & $<3$ & $788 \pm 37$ & $<3$ & $697 \pm 77$ & $<10$ & $<3$ \\
\hline 8 & $<3$ & $709 \pm 105$ & $<3$ & $803 \pm 50$ & $<10$ & $<3$ \\
\hline 9 & n.d. & $591 \pm 57$ & $<3$ & $612 \pm 5$ & $<10$ & $<3$ \\
\hline 12 & n.d. & $536 \pm 64$ & $<3$ & $548 \pm 50$ & $<10$ & $<3$ \\
\hline
\end{tabular}

Table 3 MPN results for samples 1-4 and 6. 95\% confidence intervals are in brackets. The first day of analysis for samples 4 and 6 were at day 5 , since these samples were stored in outdoor KBAL tanks for
5 days prior to sampling. There are no MPN results for sample number 5 , as only 1 bottle was collected

\begin{tabular}{|c|c|c|c|c|c|}
\hline \multirow[t]{2}{*}{ Analysis day } & \multicolumn{5}{|l|}{ Samples } \\
\hline & 1 & 2 & 3 & 4 & 6 \\
\hline 1 & $<3(0-9.5)$ & $930(180-4200)$ & $93(18-420)$ & & \\
\hline 2 & $<3(0-9.5)$ & $930(180-4200)$ & $14(36-420)$ & & \\
\hline 5 & $0.3(0.15-9.6)$ & $430(90-1800)$ & $0.92(0.14-3.8)$ & $750(170-2000)$ & $0.36(0.09-0.94)$ \\
\hline 6 & $<3(0-9.5)$ & $430(90-1800)$ & $2.3(0.46-9.4)$ & $750(170-2000)$ & $<0.3(0-9.5)$ \\
\hline 7 & $<3(0-9.5)$ & $2400(420-20,000)$ & $<3(0-9.5)$ & $430(90-1800)$ & $<0.3(0-9.5)$ \\
\hline 8 & $<3(0-9.5)$ & $750(170-2000)$ & $0.36(0.09-0.94)$ & $930(180-4200)$ & $0.92(0.14-3.8)$ \\
\hline 9 & $<3(0-9.5)$ & $240(42-2000)$ & $<3(0-9.5)$ & $430(90-1800)$ & $<0.3(0-9.5)$ \\
\hline 12 & $<3(0-9.5)$ & $750(170-2000)$ & $<3(0-9.5)$ & $4600(900-20,000)$ & $<0.3(0-9.5)$ \\
\hline
\end{tabular}

cysts formed in the dark outdoor tanks might settle down in tanks during the holding time. In addition, the exposure to UV irradiation can influence the swimming capacity of algae [31]. The numbers of live cells also varied between replicates in some of the samples, which can be explained by patchiness of organisms in the tanks at sampling. Tests have showed that the concentration of organisms in different size groups can vary in different areas inside the tanks, with high concentration of large organisms and low concentration of small organisms, and vice versa [32], explained by predator-prey interactions [33]. This highlights possible challenges with in situ conditions, and the importance of getting representative ballast water samples.

Results from all analysis methods to assess the effectiveness of KBAL, showed a reduction in the concentration of live and viable $T$. suecica cells after treatment. This is consistent with previous in vitro studies of $T$. suecica irradiated with an MP UV lamp [26, 27, 34, 35], and also other UV-irradiated microalgae [36, 37]. The cultivation based methods (plate count and MPN) revealed similar results, with a decrease in the numbers of viable cells during dark incubation (except for two outstanding high MPN results for the untreated control sample). The results show that there were $<10$ viable $T$. suecica cell $\mathrm{ml}^{-1}$ in the test water after the first treatment and the 5 day holding time. Consequently, the results confirm compliance with the IMOs discharge standard assessing reproduction already at this stage, and additional effects caused by the second treatment was, therefore, not possible to detect. However, the same samples did not meet the discharge standards of IMO and the USCG when assessing metabolism, not even after the second treatment. The different results for metabolic (living) and reproductive (viable) $T$. suecica cells after KBAL treatments, clearly highlights a challenge UV-based BWTS can encounter when meeting different testing regimes, which previously has been highlighted by several authors [38, 39].

Our results show that the number of live and viable cells were similar for the untreated control sample (sample 4). Some of the untreated cells appeared as damaged (Q2) in the start of the experiment (days 0-2); however, they were detected as live (Q1) later in the incubation period. Physical or chemical stress applied to cells can cause a temporary 


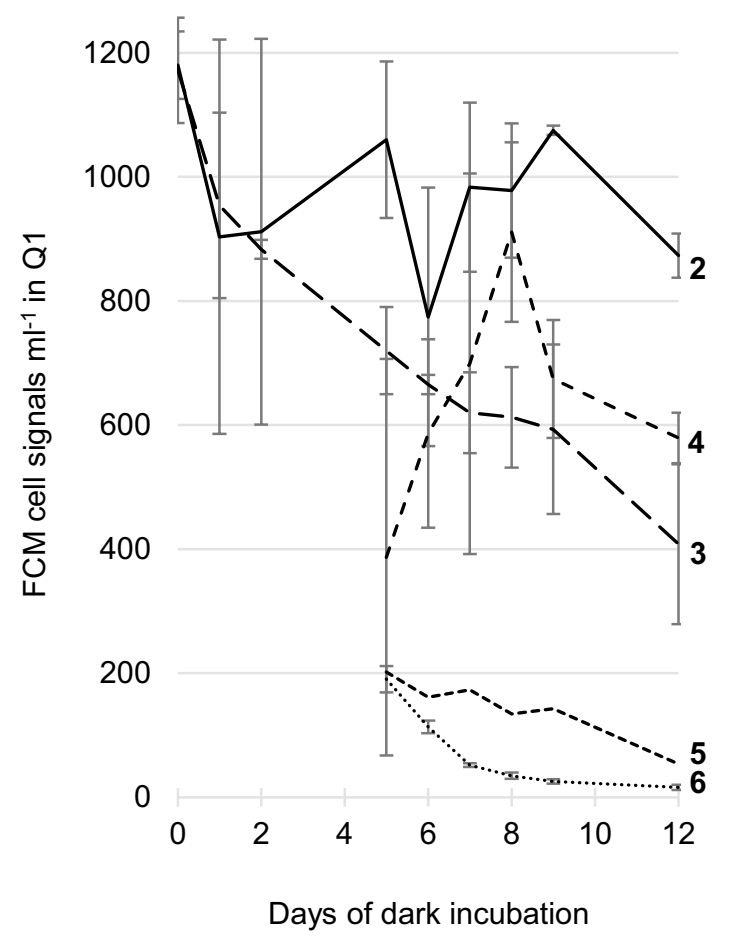

Fig. 4 Numbers of FCM cell signals in Q1 (live) during incubation for samples 2-6 (see Table 1). Sample 1, seawater, was not included in the figure, as cultivation methods did not show growth of $T$. suecica. The first day of analysis for samples 4-6 were at day 5, since these samples were stored in outdoor KBAL tanks for 5 days prior to sampling. Error bars indicate $\pm 1 \mathrm{SD}$

membrane permeability and recovery after a few days [40-42]. Even though our T. suecica cells were cultured under controllable laboratory conditions, they were diluted in natural seawater to obtain test water quality, which may have caused stress to the cells. The temperature of the seawater was lower compared to the laboratory conditions; however, many marine phytoplankton are able to tolerate high daily and seasonal temperature variations and growth can vary over a range of temperatures [6, 7]. For samples treated once with KBAL (sample 3 and 5), a decrease in esterase activity was seen immediately after the treatment and during the dark hold period, but the number of live cells were greater compared to the number of viable cells. This is consistent with previous studies of UV-irradiated T. suecica [27, 34, 35], but also to bacteria, and yeast [42]. For samples irradiated at low UV doses, no immediate shutdown of the cellular functions occur even when the reproductive capacity is lost (i.e., live but non-viable cells) [29, 38, 42, 43]. Non-viable cells may suffer from UV-induced DNA damages, which can be counteracted by DNA repair mechanisms [44]. Photorepair have been observed in T. suecica cells [45], but dark repair is not reported for T. suecica [46]. In addition, seawater turbidity can decrease the effectiveness of UV

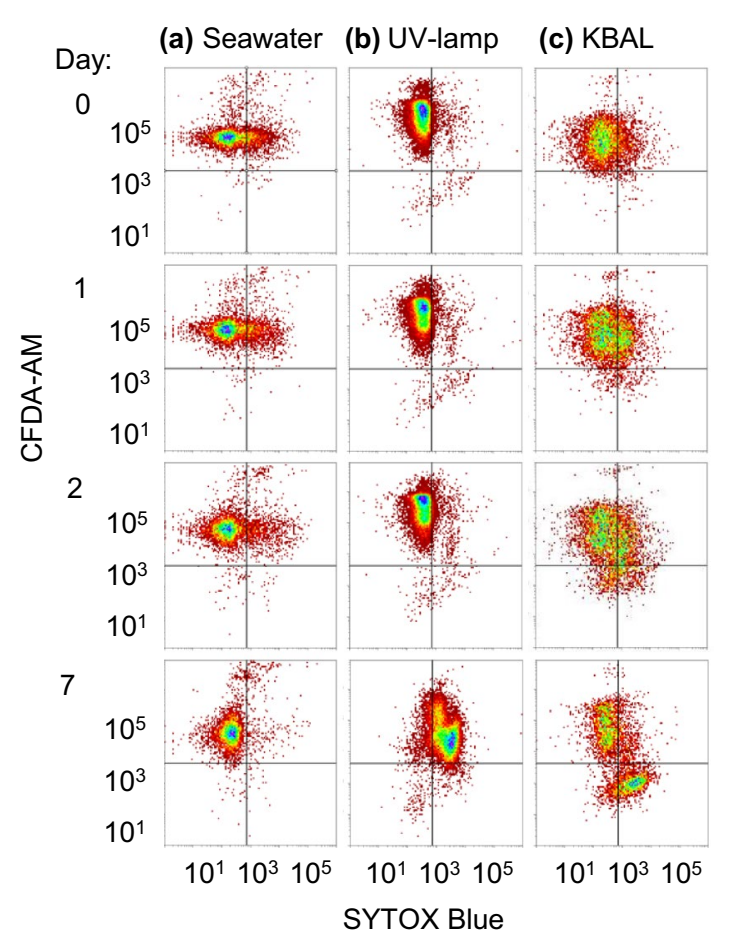

Fig. 5 FCM dot plots of Tetraselmis suecica stained with SYTOX Blue ( $x$-axis) and CFDA-AM ( $y$-axis). The vertical columns show results for a seawater, b $T$. suecica cells irradiated with an MP UV lamp at $100 \mathrm{~mJ} \mathrm{~cm}^{-1}$ [26], and $\mathbf{c}$ test water treated once at KBAL. The horizontal rows show the number of days of incubation

inactivation [46], and seawater particles and particles added to the seawater in the KBAL tank may have shielded some organisms from UV exposure. Dark incubated cells may also have low metabolic activity level [47, 48], and particle shielding during UV irradiation and low metabolic activity may have caused a delayed/no effect on the esterase activity.

Several studies have examined the use of UV irradiation in ballast water treatment, but knowledge about $\mathrm{P} / \mathrm{V}$ technology used for ballast water purification is scarce. We, therefore, compared results of $T$. suecica cells treated at the KBAL test rig, with previous results from $T$. suecica cells treated with UV irradiation only. This comparison can give indications of effects caused by the P/V technology, even though results from tests with $\mathrm{P} / \mathrm{V}$ treatment alone is lacking. Comparable UV doses were used for the KBAL testrig experiment and in $\mathrm{UV}$ only experiments $\left(100 \mathrm{~mJ} \mathrm{~cm}^{-2}\right)$, and the $T$. suecica population were followed over time after treatment. The main observation is that the $\mathrm{P} / \mathrm{V}$ technology seems to improve the disinfection effect, since $T$. suecica cells die faster after treatment with KBAL compared to UV irradiation alone (Fig. 5). This can be either an additive or a synergistic effect. The cells exposed to UV only, first lost their membrane permeability followed by a loss of esterase activity. On the other hand, cells treated with P/V and UV 
irradiation, simultaneously lost both membrane permeability and esterase activity.

For future research, it would be interesting to study the effects caused by the P/V treatment on turbidity. It will also be important to know more details on how the P/V technology effects a broader range of organisms, since the focus here have been on vitality and viability of the indicator organism T. suecica only.

Acknowledgements Open Access funding provided by Western Norway University Of Applied Sciences. This research was funded by the Norwegian Research Council (project no. 208653) and Knutsen OAS Shipping AS, and supported by Western Norway University of Applied Sciences, VRI Rogaland, UH-nett Vest, Solstad Shipping and TeknoVest. We thank Per Lothe and Bjørn Joakim Ramsen (Knutsen OAS Shipping AS, Haugesund, Norway) for helpful discussions and assistance at the KBAL test rig.

Open Access This article is licensed under a Creative Commons Attribution 4.0 International License, which permits use, sharing, adaptation, distribution and reproduction in any medium or format, as long as you give appropriate credit to the original author(s) and the source, provide a link to the Creative Commons licence, and indicate if changes were made. The images or other third party material in this article are included in the article's Creative Commons licence, unless indicated otherwise in a credit line to the material. If material is not included in the article's Creative Commons licence and your intended use is not permitted by statutory regulation or exceeds the permitted use, you will need to obtain permission directly from the copyright holder. To view a copy of this licence, visit http://creativecommons.org/licenses/by/4.0/.

\section{References}

1. IMO (2004) International convention for the control and management of ships' ballast water and sediments. International Maritime Organization, London

2. United States Coast Guard (2015) Standards for living organisms in ships' ballast water discharged in U.S. waters. Federal Register 2012. http://www.gpo.gov/fdsys/pkg/FR-2012-03-23/pdf/20126579.pdf. Accessed 21 Aug 2015

3. EPA (2010) Generic protocol for the verification of ballast water treatment technology, version 5.1. National Service Centre for Environmental Publications. https://www.epa.gov

4. IMO (2018) Code for approval of ballast water management systems (BWMS code). The marine environment protection committee (MEPC). International Maritime Organization, London

5. Lloyd's Register Marine (2019) Available ballast water treatment systems. http://info.lr.org/l/12702/2016-03-03/2ryssx/12702 /139501/Available_ballast_water_treatment_systems_2017_Versi on_1.xlsx. Accessed 18 Apr 2019

6. Samarasinghe $\mathrm{N}$ et al (2012) Algal cell rupture using high pressure homogenization as a prelude to oil extraction. Renew Energy 48:300-308

7. Wuytack EY, Diels AMJ, Michiels CW (2002) Bacterial inactivation by high-pressure homogenisation and high hydrostatic pressure. Int J Food Microbiol 77(3):205-212

8. Qian C, McClements DJ (2011) Formation of nanoemulsions stabilized by model food-grade emulsifiers using high-pressure homogenization: factors affecting particle size. Food Hydrocoll 25(5):1000-1008
9. Grigorszky I et al (2006) The Effects of temperature, nitrogen, and phosphorus on the encystment of Peridinium cinctum, Stein (Dinophyta). Hydrobiologia 563(1):527-535

10. Hallegraeff GM, Bolch CJ (1991) Transport of toxic dinoflagellate cysts via ships ballast water. Mar Pollut Bull 22(1):27-30

11. Gregg MD, Hallegraeff GM (2007) Efficacy of three commercially available ballast water biocides against vegetative microalgae, dinoflagellate cysts and bacteria. Harmful Algae 6(4):567-584

12. Bolch CJ, Hallegraeff GM (1993) Chemical and physical treatment options to kill toxic dinoflagellate cysts in ships' ballast water. J Mar Environ Eng 1:23-29

13. Mofidi AA et al (2002) The effect of UV light on the inactivation of Giardia lamblia and Giardia muris cysts as determined by animal infectivity assay (P-2951-01). Water Res 36(8):2098-2108

14. Kobayashi M, Okada T (2000) Protective role of astaxanthin against u.v.-B irradiation in the green alga Haematococcus pluvialis. Biotechnol Lett 22(3):177-181

15. Delacroix S et al (2013) Disinfection by-products and ecotoxicity of ballast water after oxidative treatment - results and experiences from seven years of full-scale testing of ballast water management systems. Mar Pollut Bull 73(1):24-36

16. Werschkun B et al (2014) Emerging risks from ballast water treatment: the run-up to the international ballast water management convention. Chemosphere 112:256-266

17. Hijnen WAM, Beerendonk EF, Medema GJ (2006) Inactivation credit of UV radiation for viruses, bacteria and protozoan (oo) cysts in water: a review. Water Res 40(1):3-22

18. Hess-Erga OK, Attramadal KJK, Vadstein O (2008) Biotic and abiotic particles protect marine heterotrophic bacteria during UV and ozone disinfection. Aquat Biol 4(2):147-154

19. Tang KW, Dziallas C, Grossart HP (2011) Zooplankton and aggregates as refuge for aquatic bacteria: protection from $\mathrm{UV}$, heat and ozone stresses used for water treatment. Environ Microbiol 13(2):378-390

20. Blatchley ER et al (1996) Ultraviolet irradiation and chlorination/ dechlorination for municipal wastewater disinfection: assessment of performance limitations. Water Environ Res 68(2):194-204

21. Nessim Y, Gehr R (2006) Fouling mechanisms in a laboratory-scale UV disinfection system. Water Environ Res 78(12):2311-2323

22. Wait IW, Johnston CT, Blatchley ER (2007) The influence of oxidation reduction potential and water treatment processes on quartz lamp sleeve fouling in ultraviolet disinfection reactors. Water Res 41(11):2427-2436

23. Norris RE, Hori T, Chihara M (1980) Revision of the genus Tetraselmis (Class Prasinophyceae). Bot Mag 93(4):317

24. Lundgreen $\mathrm{K}$ et al (2019) Use of standard test organisms for sound validation of UV-based ballast water treatment systems. Mar Pollut Bull 144:253-264

25. Sun Z, Blatchley ER III (2017) Tetraselmis as a challenge organism for validation of ballast water UV systems. Water Res 121:311-319

26. Olsen RO et al (2016) Dual staining with CFDA-AM and SYTOX Blue in flow cytometry analysis of UV-irradiated Tetraselmis suecica to evaluate vitality. Aquat Biol 25:39-52

27. Olsen $\mathrm{RO}$ et al (2016) Ultraviolet radiation as a ballast water treatment strategy: inactivation of phytoplankton measured with flow cytometry. Mar Pollut Bull 103(1):270-275

28. U.S. Food and Drug Administration (FDA) (2010) Bacterial analytical manual, appendix 2 most probable number from serial dilutions. http://www.fda.gov/Food/FoodScienceResearch/Laboratory Methods/ucm109656.htm. Accessed 21 Aug 2015

29. Davey HM (2011) Life, death, and in-between: meanings and methods in microbiology. Appl Environ Microbiol 77(16):5571-5576 
30. Carney KJ et al (2013) Difficulties in obtaining representative samples for compliance with the ballast water management convention. Mar Pollut Bull 68(1-2):99-105

31. Ma ZL et al (2012) Motility and photosynthetic responses of the green microalga Tetraselmis subcordiformis to visible and UV light levels. J Appl Phycol 24(6):1613-1621

32. Gollasch S, David M (2017) Recommendations for representative ballast water sampling. J Sea Res 123:1-15

33. Rosenzweig ML, MacArthur RH (1963) Graphical representation and stability conditions of predator-prey interactions. Am Nat 97(895):209-223

34. Olsen RO et al (2015) Flow cytometric applicability to evaluate UV inactivation of phytoplankton in marine water samples. Mar Pollut Bull 96(1-2):279-285

35. Lundgreen $\mathrm{K}$ et al (2018) UV fluences required for compliance with ballast water discharge standards using two approved methods for algal viability assessment. Mar Pollut Bull 135:1090-1100

36. Romero-Martinez L et al (2016) Evaluation of ultraviolet disinfection of microalgae by growth modeling: application to ballast water treatment. J Appl Phycol 28(5):2831-2842

37. Casas-Monroy O et al (2016) Comparison of three techniques to evaluate the number of viable phytoplankton cells in ballast water after ultraviolet irradiation treatment. J Appl Phycol 28(5):2821-2830

38. Blatchley ER et al (2018) The biological basis for ballast water performance standards: "viable/non-viable" or "live/dead"? Environ Sci Technol 52(15):8075-8086

39. Gerhard WA et al (2019) Installation and use of ballast water treatment systems-implications for compliance and enforcement. Ocean Coast Manag 181:9

40. Shi L et al (2007) Limits of propidium iodide as a cell viability indicator for environmental bacteria. Cytometry Part A 71A(8):592-598
41. Davey HM, Hexley P (2011) Red but not dead? Membranes of stressed Saccharomyces cerevisiae are permeable to propidium iodide. Environ Microbiol 13(1):163-171

42. Schenk M et al (2011) Inactivation of Escherichia coli, Listeria innocua and Saccharomyces cerevisiae by UV-C light: study of cell injury by flow cytometry. LWT-Food Sci Technol 44(1):191-198

43. Kramer B, Muranyi P (2014) Effect of pulsed light on structural and physiological properties of Listeria innocua and Escherichia coli. J Appl Microbiol 116(3):596-611

44. Sinha RP, Häder DP (2002) UV-induced DNA damage and repair: a review. Photochem Photobiol Sci 1(4):225-236

45. Hull NM et al (2017) Algal DNA repair kinetics support culturebased enumeration for validation of ultraviolet disinfection ballast water treatment systems. Environ Sci Technol Lett 4(5):192-196

46. Liu L et al (2016) Effects of water quality on inactivation and repair of Microcystis viridis and Tetraselmis suecica following medium-pressure UV irradiation. Chemosphere 163:209-216

47. Carney KJ et al (2011) The effects of prolonged darkness on temperate and tropical marine phytoplankton, and their implications for ballast water risk management. Mar Pollut Bull 62(6): 1233-1244

48. Jochem FJ (1999) Dark survival strategies in marine phytoplankton assessed by cytometric measurement of metabolic activity with fluorescein diacetate. Mar Biol 135(4):721-728

Publisher's Note Springer Nature remains neutral with regard to jurisdictional claims in published maps and institutional affiliations. 